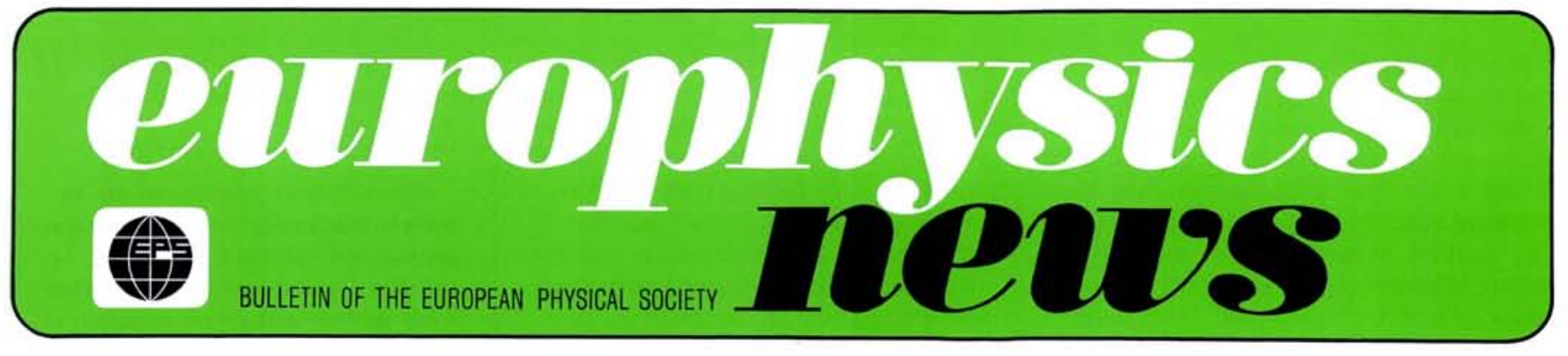

J.A. Volume $13 \quad$ Number 5

May 1982

\title{
EPS COUNCIL 1982
}

\section{Report on the Meeting of the Council of the European Physical Society held in Geneva, 1/2 April, 1982}

The Council of EPS met in Geneva on $1 / 2$ April 1982 following meetings of the Advisory Committees on Finance, Physics Education, Physics and Society, and Publications, and also the Executive Committee. Originally it had been planned to hold the meetings in Leningrad in association with an EPS seminar on joint projects, but by the time the administrative formalities had been completed, it was too late to organize the seminar as a truly European exercise and the Academy of Sciences of the USSR decided to postpone the invitation to a later time.

In his report to Council, the retiring President, A.R. Mackintosh, laid stress on the fundamental importance to the Society of the Divisions through whose activities the scientific life of the Society was developed. The chairmen of the Divisions were now invited to the meetings of the Executive Committee and this had resulted in a closer identification of the Divisions with the overall operations of the Society and a greater awareness in the Executive of the activities of the Divisions and Sections. Two new Advisory Committees had been created. The Finance Committee had the continuous objective of generating sources of income to give the Society a sound economic basis and so avoid the seesawing between crisis and complacency that had tended to mark the Society's history. The Scientific Freedom Committee had been formed in response to concern on the part of Individual Members about alleged infringements of the rights of European physicists. The main responsibility of this Committee was to investigate such allegations and report to the Executive. Both Committees were now exerting an influential role in the Society.

The President had attached considerable importance to the Society's publications Europhysics Conference Abstracts and the European Journal of Physics and it was a source of satisfaction that the first, through the cooperation of the Divisions, was now an economic asset to the Society while the second (q.v.), after a slow start was on the way to matching its financial record to its intellectual success. It was nevertheless clear that Members had not exerted the individual influence they could to make these publications more widely circulated.

Significant progress had been registered in our relationships with other organisations. Discussions with the American Physical Society now opened the way to a fruitful collaboration, details of which will be given in future issues of Europhysics News, and we had established contacts with the European Science Foundation which could lead to a combined approach to giving assistance in education and research to developing countries. The APS had agreed to sponsor jointly the Symposium on International Facilities for Physics Research that was to be held in conjunction with the 1983 Council Meeting in Copenhagen beginning on 21 March. Cooperation with UNESCO had been especially active, with joint meetings in Erice and Istanbul on employment and the problems of physics in the less developed countries in Europe (organised through the Physics and Society Committee) and a joint meeting in Paris on publishing practices (arranged through the Publications Committee). Further joint meetings to study summer schools, help with travelling costs, jobs and the use of UNESCO coupons were planned.

\section{Helping Polish Physicists}

Council was informed of the strong feeling of solidarity that had been generated within the physics community over the economic problems in Poland which had resulted in the cancellation of funds for the purchase of scientific literature published outside the country. Several initiatives had been taken to try and ensure the necessary flow of physics information. For example, a fund had been opened in France at the Gif-sur-Yvette agency of the Crédit Lyonnais (F-91190 Gif-sur-Yvette) No. 896800 $3011 \mathrm{R}$ ) for the purchase of publications; The Institute of Physics and Editions de Physique were sending copies of all their publications to Poland; North-Holland was sending some and a number of editors were sending their private copies to Polish colleagues.

At CERN, a rather different form of aid had been instituted through Assistance Pologne (c/o CERN, CH-1211 Geneva 23) where an account had been opened (SBSCERN-C7-103118.0) to collect funds for the purchase of medical supplies. Already some $400 \mathrm{~kg}$ had been transferred into the care of the Archbishop of Warsaw.

\section{Arms Limitations}

A draft statement has been received from the National Committee of Soviet Physicists protesting against the deployment of new nuclear missiles in Europe, together with the suggestion that this statement should be adopted by the EPS

\section{Contents}

EPS Council 1982

Council Meetings 1983-1986

Swiss Physical Society

2nd General Conference of the CMD

Inverse Problems in Optics

Call for H-P Prize Nominations

Surface Reaction Dynamics

1
3
3
4
6
8
9
3

8 9 
and sent to the Second Special Session of the United Nations General Assembly on Disarmament. This suggestion had been discussed in the Executive Committee, where there was a consensus that the previous policy of the Society against issuing political statements, on matters in which physicists have no special competence, should be maintained. The Council concurred with this recommendation.

\section{Divisions}

Divisional activity is primarily evident through the major conferences organized each year. In the following, brief extracts are given of the oral reports presented to Council.

Astronomy and Astrophysics: New life had been breathed into the Division and following the highly successful seminar on neutron stars during the 5th General Conference, a workshop on comets had been organized for November 1982 in Budapest. The Board was to be meeting soon to discuss in depth the level of activity that should be aimed for, to cater for what was really a big community with a large number of specialised interests.

Atomic Physics: Following the recommendations made to Council in Istanbul, approval was given for the name of the Division to be changed to Atomic and Molecular Physics Division as announced last month.

Computational Physics Group: A particular problem for the Group at this time was that the Chairman was in Poland and the next Group Conference had been arranged there. The Conference would have to be postponed and meanwhile the former Chairman, F. James would be looking after the Group. One of its most exciting ventures was the production of handbooks for physicists setting out algorithms and methods of working. The first, directed to high energy physicists, had shown the complexity of the job but the latest version compiled at CERN should be available soon as an EPS publication. Atomic physics would be the next subject to be treated.

Condensed Matter: The Second General Conference of the Division, held in Manchester, 22-25 March 1982 had been another success (see p. 4) and the series could now be considered established. The 1983 meeting would be in Lausanne, 1984 in The Hague and 1985 probably in the Federal Republic of Germany. A general meeting of the Division had been held in Manchester which attracted 100 participants and had produced very lively discussions. It was evident that in the younger generation the European concept was an accepted fact.

High Energy and Particle Physics: The 1981 Conference in Lisbon had been not only an excellent scientific meeting, but it had been accompanied by a major interaction with the general public that had at- tracted wide interest. The scene moreover had been set for an understanding to be reached between Portugal and CERN. The Conference had benefited from a major contribution to the funding from the Portuguese community and Council considered it right that a substantial fraction of the profits from the Conference should be used to help Portuguese physicists. It is, however, for the Division which has autonomy in the disposal of its funds, to judge.

Nuclear Physics: Considerable interest was expressed in the coming symposium in Copenhagen, because it is a time in the nuclear physics field when new facilities are becoming available and a number of new proposals are coming forward. (One can note that the European Science Foundation has formed two study groups, one to consider neutron beam research and the other "low energy" nuclear research.)

Plasma Physics: The 10th Divisional Conference which had been held in Moscow had given valuable insight into fusion research in the Soviet Union. The next in September 1983 will be held in Aachen when for the first time the new rules on those eligible to present papers will be in force.

The proposed Optics Division: No specific steps were taken pending a meeting of the European Optics Committee at which their adherence to EPS was to be determined.

\section{Changes to Constitution and By-Laws}

The changes to the Constitution and ByLaws announced in the December 1981 issue of Europhysics News were agreed, as published in last month's issue. In the discussion it was underlined that, whilst it was difficult to make more precise the definition of a Collaborating Society, it was clearly a Society that was not really eligible to become a 4b) Member either, because the seat lay outside Europe or, because its prime function was not physics. In any case, Council would discuss each case on its merits and would be defining also the membership fee, case by case.

Council was then able unanimously to approve the designation of the American Physical Society as a Collaborating Society and fix the fee for members of APS to become Members of EPS category 4d) at five units, equivalent to 4 units for a $4 \mathrm{c}$ ) Member plus one unit contribution from the person's Society. For 1982 this amounts to Sw.Frs. 45. - which may be commuted to 25 US\$.

There was a great deal of support for the idea of a student membership for a reduced fee, introducing a maximum age or perhaps better, period of applicability. This raises however important questions of eligibility in view of the different rules operating within the national societies. A first step therefore will be to collect data on current practices to see whether a further class of membership needs to be created and if this can be done without favouritism.

Council then went on to approve the proposal that senior physicists should be able to remain members of EPS after their retirement from remunerative work, for an annual subscription equal to half the normal rate. A number of definitions of retirement were aired but finally it was concluded that the solution was simply to require that retired members apply to the Secretariat for the reduced rate, and to consider such applications individually.

\section{SPIE}

Council approved the agreement concluded between EPS and the International Society for Optical Engineering (SPIE) whereby EPS, for a significant fee, provides administrative services in Europe for this American-based but international organization. It was emphasized that the contract with SPIE would not imply an endorsement by EPS of its activities. On the other hand, the income acquired will be very welcome, especially in the light of the withdrawal two years ago of the European Nuclear Society from a similar arrangement with EPS.

\section{Finances}

In round terms, the provisional accounts for 1981 in convertible currency show an overall excess of expenditure over income for the year of Sw.Frs. 36000.-. Adding depreciation and subtracting the withdrawal from the Special Development Fund (leaving it empty) the net deficit is Sw.Frs. 20000.-. This cannot be considered a satisfactory result and great efforts have been made to bring the 1982 budget more or less into balance. The investment in the European Journal of Physics is expected to be halved, but more income is still needed from Members - both Individual and Associated, more advertising in Europhysics News... Clearly a sustained effort is going to be needed to keep the Society's finances healthy and ways must be found of usefully employing the non-convertible funds which currently are worth (depending on the conversion rate used) some Sw.Frs. 120000.-.

The Advisory Committee on Finance is convinced that there are many potential recruits for individual membership and the impressive list of new Associate Members, notably from France, indicates the potential source of interest in that category. New recruiting literature is needed in the form of pamphlets and posters etc. and these will be prepared. More use should also be made 
of the differential conference fee to make individual membership more attractive.

With only one delegation opposing (the USSR Academy of Sciences) Council approved an increase in unit fee from Sw. Frs. 9. - to Sw.Frs. 10. - to come into force after 31 December 1982, as and when the Executive Committee judged that inflation in Switzerland and the state of the Society's finances justified such an increase. Council also agreed that at the same time an increase be applied, the subscription for 4a) members would be reduced from 14 to 12 units.

\section{New Members}

In last month's issue of Europhysics News the list of new members was published. It included in addition to many individuals, one new 4b) member (the Iceland Physical Society) and 10 new Associate Members. Council was happy to hear that the Hellenic Physical Society which had been in suspense because of difficulty in meeting its payments was returning as a normal member.

\section{Scientific Freedom}

In the discussion on scientific freedom, notable for its moderate tone, it was clear that "freedom" had its economic as well as its political limitations. It was natural to plead for special provisions to be made for certain well-known scientists but the problem of finding funds for paying conference enrolment fees and travel was general. It was impossible for EPS to legislate on such a matter, particularly as the provision (or not) of funds for attending scientific conferences was a matter for internal political decisions in each country. The uncomfortable reality was that conference fees could only be waived for some by raising them for others, and travel costs had to be paid by someone. The only way that help could be given was by the organizers of a given conference acting on their own initiative (in consultation with the Division).

On the question of political restrictions, the Committee had received some cooperation in its fact-finding, relating to the five cases that had been referred to it. In some instances however it had not even been acknowledged that a letter of enquiry had been received, and delegates were urged to help ensure that at least this was done in their own countries. Of the five cases referred to above: in one, assurances had been received that an invitation to do research abroad could be accepted, in another, a physicist accused of contravening the law had been released pending trial, whereas in the other three, concerned with confiscation of mail, harassment of participants at a private seminar, and unfair dismissal, no response had been forthcoming from the relevant scientific body. The action to be taken was a matter for the Executive Committee after having explored all the consequences of its decisions.

\section{Publications}

Council was pleased to note the up-turn in orders for the European Journal of Physics which was having a real impact now in the USA through the "package marketing" scheme of the Institute of Physics. Present orders for Volume 3 were above 620 and it only needed a vigorous push by the EPS Members for the journal to become established and profitable. In a number of committees and in the corridors, discussions were held on the level of article published, and the question was raised whether they were not perhaps on average a little too academic. No doubt the editor, G.W. Series, will be pondering the generous advice he has received.

Negotiations over a European physics letters journal had not reached the point where a clear proposition could be put before Council and the enquiry within the Divisions had revealed a wide range of opinions about the adequacy of the present letters journals. These were, in any case, changing to take account of criticisms that had been made. Nevertheless, Council was reluctant to give up at this stage and the Chairman of the Publications Committee, G. Eilenberger, was urged to continue his discussions, particularly with the three physical societies most directly involved those of France, Italy and the UK. He will also be following up proposals made by North-Holland for an EPS participation in the publication of Physics Letters A.

\section{Young Physicists Fund}

One of the most controversial provisions within the EPS has been the imposition of a levy of one unit fee per participant in EPS organized conferences to provide a fund for sending young physicists to the General Conference. Many conference organizers resented this on principle, believing that specialist conferences were, in any case, more important. The dissension the disagreements provoked was considered by many to out-weigh the financial return. On the other hand, it was felt that such an activity was necessary even if funding had to come from the central budget. Various formulae for raising money and dividing it with the Divisions were considered, but finally it was agreed that as the fund had sufficient money at present to cater for the next General Conference, contributions should be made optional and Divisions invited to consider how for their own conferences they could best fund the attendance of a number of young people.

\section{Elections, Future Meetings}

Finally, as announced in the April issue of Europhysics News, Council elected a new Executive Committee under a new President, Professor Friedel, gratefully accepted the proposal from the Physical Section of the Union of Czechoslovak Mathematicians and Physicists to hold the next
General Conference in Prague in late August 1984, heard details of the Symposium on International Facilities for Physics Research and determined the dates of its meetings up to 1986 (see below).

\section{Evening Lectures}

As guests of the Universty of Geneva, Council was treated to a lecture given by Professor Herwig Schopper, Director General of CERN, on the future prospects in high energy physics. This was followed by a persuasive talk on the interest and value of the European Journal of Physics, given by the editor.

\section{Council Meetings}

Meetings of Council in the next four years will be held in the week beginning:

1983: 21 March Copenhagen

1984: 26 March

1985: 25 March

1986: 17 March

Member organizations of EPS who are interested in hosting one of these Council meetings are asked to write to the Executive Secretary indicating the year preferred with possibly an alternative.

\section{Swiss Physical Society}

On the retirement of Prof. G. Wanders after 17 years service as chief editor of Helvetica Physica Acta, the Editorial Board announces the appointment of $\mathrm{Ph} . \mathrm{A}$. Martin as his successor. While maintaining the tradition of a high scientific standard, the journal intends to open its pages to contributions of a slightly more diversified nature: H.P.A. will henceforth accept contributions from all branches of physics without restrictions as to their origin or to the nationality of their authors.

To provide the possibility of communicating results without strict limitations on length, it will publish experimental and theoretical work of an extended and detailed format which may not be routinely accepted in specialized reviews. In particular, it is proposed to publish original and well written doctoral dissertations. It is intended also to accept reviews and articles of a didactical nature as well as to solicit papers of general interest.

In order to facilitate the publication of extended articles, page charges will be limited to Sw.Fr. 10. - /page and to a maximum of Sw.Fr. 120.-/article. In addition, it may prove possible to provide thesis reprints at a reduced price upon request.

The journal will appear in $4-6$ issues annually at regular intervals. Prospective authors are invited to submit their contributions to Ph.A. Martin, Editor, Institut de Physique Théorique, EPFL - PHB Ecublens - CH-1015 Lausanne, Switzerland.

G.R. Plattner \& Ph. A. Martin 